\title{
The effects of thinning treatments on density, MOE, MOR and maximum crushing strength of Pinus brutia Ten. wood
}

\author{
Bilgin GULLER* \\ Suleyman Demirel Universitesi, Orman Fakultesi, Isparta, Turkiye
}

(Received 9 November 2005; accepted 30 May 2006)

\begin{abstract}
The purpose of this study was to determine the effects of plantation thinning on various wood properties of Pinus brutia Ten. Tree samples were obtained from heavily and moderately thinned and unthinned 33-35 year-old plantations. Wood properties were examined in various wood zones including 16 annual rings after the first treatment. The results of this study showed that there was a significant relationship between thinning intensity and radial increment $(1.30 \mathrm{~m})$ for an individual tree. Thinning treatments increased annual ring width especially a few years after thinning. Heavy thinning treatments were especially effective in impacting mean ring width values at breast height. However, the percentage of late wood did not differ much between the samples. Based on the results of correlation analysis between ring width and late wood percentage there was no significant correlation identified. Mean wood density was not affected by the treatments. Also, no significant correlation was found between thinning and examined strength properties (MOR, MOE and compression strength parallel to grain). However, a relationship was found between wood density and all strength properties except for MOE. The current results suggest that thinning can produce improvements in ring width without any negative impacts on investigated wood properties. It is recommended that subsequent studies should be designed to understand genetic effects and maximize treatment effects.
\end{abstract}

Pinus brutia Ten. / thinning / wood properties

Résumé - Effets de l'intensité des éclaircies sur la densité, les modules d'élasticité et de rupture et de rupture transversale du bois de Pinus brutia Ten. L'objectif de cette étude était de déterminer l'effet d'une éclaircie sur quelques propriétés du bois de Pinus brutia Ten. de plantations. Les arbres proviennent de plantations âgées de 33-35 années, fortement, modérément ou non éclaircies. Les propriétés du bois ont été examinées dans une zone incluant 16 cernes annuels après le premier traitement. Les résultats de cette étude montrent qu'il existe une relation positive significative entre l'intensité de l'éclaircie et l'incrément radial $(1.30 \mathrm{~m})$ de bois pour un arbre individuel. Les traitements d'éclaircie ont augmenté la largeur des cernes particulièrement dans les années ayant suivi l'éclaircie, et il y avait un net effet des traitements d'éclaircie notamment des fortes éclaircies, sur la largeur de cerne moyenne à hauteur de poitrine. Toutefois le pourcentage de bois final variait peu. L'analyse de corrélation entre largeur de cerne et le pourcentage de bois final n'a pas montré de relation significative. La densité moyenne du bois n'était pas affectée par les traitements. Dans cette étude, aucune corrélation significative n'a été observée entre l'éclaircie et les propriétés mécaniques étudiées (résistance en flexion, rigidité en flexion, et résistance en compression dans le sens du fil). Une relation linéaire positive a été obtenue entre la densité du bois et les propriétés de résistance mais pas avec la rigidité. Les résultats présents suggèrent que l'éclaircie peut améliorer le cerne annuel sans aucun impact négatif sur les propriétés du bois examinées, toutefois les études à venir devront être mieux conçues pour minimiser les effets génétiques et maximiser les effets du traitement.

Pinus brutia Ten. / éclaircie / propriétés du bois

\section{INTRODUCTION}

There has been an ever increasing demand for wood products in Turkey as in many other countries of the world. As a result, the gap between wood supply and demand is rapidly widening. To solve this problem, the Turkish Ministry of Environment and Forestry has established large wood plantations and is planning to establish further plantations (http://www.cevreorman.gov.tr/). Pinus brutia is the primary species for plantation programs in Turkey, due to its rapid growth rate compared with other natural pine species in plantation areas $[12,19,57]$. This species has been used for many different products in the forest products industry, including timber, furniture, pulp and board products, fuel wood, win-

* Corresponding author: bilginguller@ orman.sdu.edu.tr dow and door framing, flooring, structural material in home construction, package, etc. [5, 19].

Because it is important to produce wood quickly and efficiently, thinning has become common practice in Turkish forestry. Thinning has proven to be an effective method in increasing radial increment of $P$. brutia and has been the subject of numerous studies. Correlations between wood properties, such as ring width, wood density, fibre length and strength properties, and the quality of wood have long been established and are classically used to characterize wood for the forest product industry. Wood density is considered a good indicator of several other wood properties and is relatively easy to measure. Thus, the relationship between wood density and thinning has been well discussed in the literature $[6,8,15,29,43]$. However, one area in which research has been neglected is that of understanding the relationship between thinning and its impact on other wood properties. For example, fibre length has 
a significant effect on a number of pulp and paper properties, including tear resistance and tensile, fold and burst strength. In most cases long fibre length is preferable [23]. Thus, it is important to understand thinning effects on other wood properties also.

Various and conflicting results exist in the literature regarding the relationship between thinning and growth rate and wood density and other wood properties. Bendtsen reported that the effect of accelerated growth on wood properties is minor compared to the differences between juvenile and mature wood properties of the same species [6]. Cown, Erickson and Harrison, Smith, Shepard and Shottafer, Barbour et al., reported a negative correlation between wood density and thinning treatments $[3,14,18,47,50]$. On the other hand, there were some reports that thinning treatments caused an increase on wood density $[35,62,63]$. Zobel and van Buijtenen reviewed a number of publications on the relationship between thinning treatments and wood density, and concluded that wood density was not greatly affected by thinning [65]. Based on different tree species, Hapla, Barrett and Kellogg, Harnnrup and Ekberg, Koga et al., and other researchers supported the idea that thinning had little or no effect on wood density [4, 20, 22, 26, 28, 31, 38-40, 45, 46, 66]. McKimmy, as well as Koga and Zhang, concluded that wood density is more significantly influenced by the environment and seed source and not greatly influenced by growth rate [28,37]. Zhang reported a negative correlation between growth rate and specific gravity and other mechanical properties of two Abies species [64]. Though some reports have indicated that thinning increased latewood percentage of Pinus taeda and Douglas-fir (Pseudotsuga menziesii) $[24,48]$, others have reported that thinning resulted in a slight decrease in latewood percentage [3, 18]. Still yet, there are some reports that show that thinning has little or no effect on latewood percentage of Douglas-fir [10], Pinus radiata [14], Pinus taeda [40], Pinus ponderosa [36], Larix leptolepis [26,27].

In contrast to the abundance of wood density research, there is relatively little research available on other wood properties. Hapla concluded that thinning treatments had little (for Douglas fir) or no significant (for Cedrus atlantica) effect on wood strength properties [20,21]. Macdonald and Hubert recommended slower growth rate and longer rotations for quality saw logs of Sitka spruce [34]. Some research indicated that tracheid length was not affected by thinning $[22,66]$. But, Koga et al. reported that thinning, in particular heavy thinning reduced tracheid lengths at breast height [26]. It has also been reported that thinning causes an increase in annual ring width and stem volume in individual tree, but also produces more tapered trees [12, 16, 17, 21,39, 42, 44, 58, 63].

Thus, based on literature, it is understood that genotype and environmental factors (soil, climate, location, altitude etc.) have a significant impact on wood properties. It is also understood that the effect of thinning on wood properties varies with many different factors including species, initial spacing, site quality, intensity and type of thinning, tree age, stem position etc. $[5,27,33,41,65]$.

But, to more efficiently manage plantations and utilize wood supply, it is essential to assess the effects of thinning treatment on wood quality attributes for $P$. brutia species. So, the major contribution of this study will be to compare the effects of different intensities of thinning on various wood properties of young Pinus brutia. This research can then be used to facilitate modelling of thinning on the species, and establish a base for silvicultural plans and further research.

\section{MATERIALS AND METHODS}

The trees used for the present study were harvested from evenaged (33-35 year-old) plantations in the south-western part of Turkey. The trees in these plantations were initially established at $3 \times 1.5 \mathrm{~m}$ spacing in 1969 and 1971 at two sites, in Isparta and Antalya, and two site classes, poor and medium. Three replicated plots of heavy thinning, moderate thinning, and control were established. The first thinning treatments (thinning from below) were applied in 1985. In the heavily thinned plots, 34-40\% of basal area was removed. In the moderately thinned plots, $15-20 \%$ of basal area was removed. Thinning was repeated every five years. However, after the first thinning, there was no set proportion for the number of trees removed except for the removal of all depressed, dead and dying trees. The present study started at the end of the growing season in 2003, 18 years after first treatment. With the aim to avoid errors due to debarking and cutting of samples, the analysis included only the wood zone for the 16 years from the first treatment.

Prior to the start of this research in 2003 the site index of the stands had been established by Usta [57].

The first experimental area, in Isparta-Asagi Gökdere, is located at an average altitude of $400 \mathrm{~m}$ and the second area, in Antalya-Kas, at $240 \mathrm{~m}$. The mean annual precipitations of the experimental areas is about $744.4 \mathrm{~mm} /$ year and $751 \mathrm{~mm} /$ year and the yearly average temperature are $12.95^{\circ} \mathrm{C}$ and $19.49^{\circ} \mathrm{C}$, and prevailing winds are SSE and NNE, respectively. All climatic data were obtained from the Egirdir and Kas meteorology stations located near the research areas. The annual mean temperatures of these areas were calculated according to the Thornthwaite method based on 30 years of records from these stations. Soil is similar in the two experimental areas. A more detailed description of the experimental areas and trees is presented by Guller [19].

Unfortunately, in Turkey, only a few plantation areas are being and have been managed for research purposes and thus the studied plantations are unique and valuable. Therefore, it is essential to preserve these areas for future research as much as possible. Due to the fact that some destructive methods were necessary and used for this research, it was very important to decide only minimal tree sample sizes.

For this research, 36 plots were chosen, based on 2 sites, 2 site classes, 3 treatments, and 3 replications for every treatment. One representative tree (quadratic mean trees of plot) was cut from every plot. But, due to natural defects (cracks, knots etc.) and the limited diameter of some trees, the representative sample size for some tests was reduced, especially for mechanical tests. At the beginning, mechanical tests were conducted with the same sample size and the results were analyzed to determine if the sample size was large enough to obtain low experimental error. The results showed that sample size were insufficient for some groups (AG2 control plots, K1 moderate thinning plots, and $\mathrm{K} 2$ heavy thinning plots). Consequently, more trees were removed from these relevant plots and a total of 41 trees were used for the study. The trees ranged in size of $12-19 \mathrm{~cm}$ breast height diameters and $9-15 \mathrm{~m}$ heights from the various thinning regimes. 
The aim of the study was to investigate thinning effects on the wood properties. Based on this type of analysis, it was essential to identify the wood zones and conduct sampling properly. To decide sampling heights, relevant standards and previous literature were used to verify methods (i.e.; for density, ring width and fibre length $[26,39])$. After obtaining wood disks from the various heights of stems, a good cutting plan was required to avoid sampling errors. Thus, before debarking the disks, one surface of all of the disks were sanded and scanned with a high resolution scanner and the first thinning time (1985) was verified by counting 18 annual rings (years) from bark. In this way the starting point of the wood zone after thinning was determined using an image analysis system. The two last annual rings from 2002 and 2003 were excluded from the analysis due to possible damage caused by debarking and cutting of the samples. The annual rings prior to thinning treatment and the two outer annual rings were removed from density and mechanical analysis.

A common error in evaluating the relationship between growth rate and wood properties is in the confounding of the growth rate and cambial age [65]. Therefore, the tree samples were obtained from even-aged plantations and sampling was based on the number of annual rings and not the distance from pith or bark.

\subsection{Measurement of annual ring width and latewood percentage}

Five $\mathrm{cm}$ thick discs were taken at $0.30,1.30,2.30$ and $2 \mathrm{~m}$ intervals from a $2.30 \mathrm{~m}$ height. These discs were used to measure annual ring width and latewood percentage. Each disc was stored at room conditions. The discs were then sanded with an orbital sander to obtain a clear surface for scanning. All discs were then conditioned in a special cabinet (Nuve ID-501) until they achieved 12\% moisture content according to TS 642 (ISO 554) [53]. Then each disc was scanned with a high resolution scanner (600 dpi). The geometric deformations induced by the scanner have been measured by scanning a grid of known dimension. This allows for the correction of the ring width measurement performed on the scanned image. These images were subjected to image analysis in order to measure annual ring width and late wood width. Pinus brutia ring boundaries have high colour contrast and earlywood and latewood are distinguished by the colour contrast. To measure these properties, the ImageJ 1.28u (public domain by Rasband W.) program was used. The latest version of this program can be found at http://rsb.info.nih.gov/ij. Latewood percentages were calculated based on the latewood widths of the growth rings divided by the total width of the rings. Measurements were made on each disc at a $90^{\circ}$ angle to the prevailing wind direction.

\subsection{Measurement of wood density}

Stem discs were taken from a stump height of $2.30 \mathrm{~m}$ at 1.30, 2.30 and $2 \mathrm{~m}$ intervals for density measurement. Each disc was marked to identify the wood zones after treatments. Blocks were then cut from discs. Wood density was calculated as the sample oven dry weight divided by the sample volume. Volume dimensions were measured with electronic calipers. All disk values from the various intervals of the stems were used to calculate mean density value of trees.

\subsection{Measurement of fibre length}

The wood blocks taken from breast height and having 16 annual rings after treatment were used to determine fibre length. Prior to maceration, a calculation of the approximate fiber length in each annual ring and the sample size for making statistically significant analysis for each group was determined. Then all annual rings samples were macerated. Maceration was conducted according to Jeffrey's method [7,8]. A total of 1023 unbroken tracheids were measured using a light microscope and micrometer.

\subsection{Measurement of strength properties}

The samples for strength properties were cut from remaining stem parts subsequent to stem disk preparation (for volume, density, and ring width measurement). The remaining wood was used up to $4.30 \mathrm{~m}$ in height of the trees. To avoid sampling errors, a good cutting plan was required. For this purpose, prior to debarking, the wood zone after treatment was measured. According to industrial standards, it was possible to obtain compression $(2 \times 2 \times 3 \mathrm{~cm})$, MOE $(2 \times 2 \times 35 \mathrm{~cm})$ and MOR test $(2 \times 2 \times 30 \mathrm{~cm})$ samples from the wood zones. The graduation of tree diameter relative to the height was observed and natural defects were recorded. Then, the cutting plans were applied. The annual rings prior to thinning treatment and two outer annual rings were removed from mechanical test samples during the cutting process. Therefore, mechanical testing was carried out on small wood samples obtained from a wood zone including 16 annual rings subsequent to first thinning treatments.

Modulus of rupture (MOR), modulus of elasticity (MOE), compression strength parallel to grain (maximum crushing strength) and density-strength relationship were investigated. Experiments were conducted according to Turkish standards (TS 2474, TS 2478, TS 2595) [54-56] (these standards are the same ISO 3133, ISO 3349 and ISO 3787).

\subsection{Statistical analysis}

All data were analyzed based on site, site classes and thinning regime. Thinning effects of investigated wood properties were examined for every site and site class using univariate variance analysis (one-way ANOVA) and post hoc test based on the results of homogeneity (Levene) tests. Correlation analysis was performed to show the relationship between wood properties and thinning treatments. Paired sample $T$-test was performed for annual ring width and late wood percentage. All statistical tests were considered significant when $P<0.05$. SPSS 13.0 statistical software was used for this analysis. The following identifiers were used for sample groups; AG1: Asagi Gokdere medium site quality, AG2: Asagi Gokdere poor site quality, K1: Kas medium site quality, K2: Kas poor site quality and 1: Control, 2: Moderate thinning, 3: Heavy thinning.

\section{RESULTS AND DISCUSSION}

\subsection{Annual ring widths and latewood percentages}

The paired sample $T$-test was performed in order to show differences in the annual ring width and late wood percentage between for the various treatments at the same sites and 

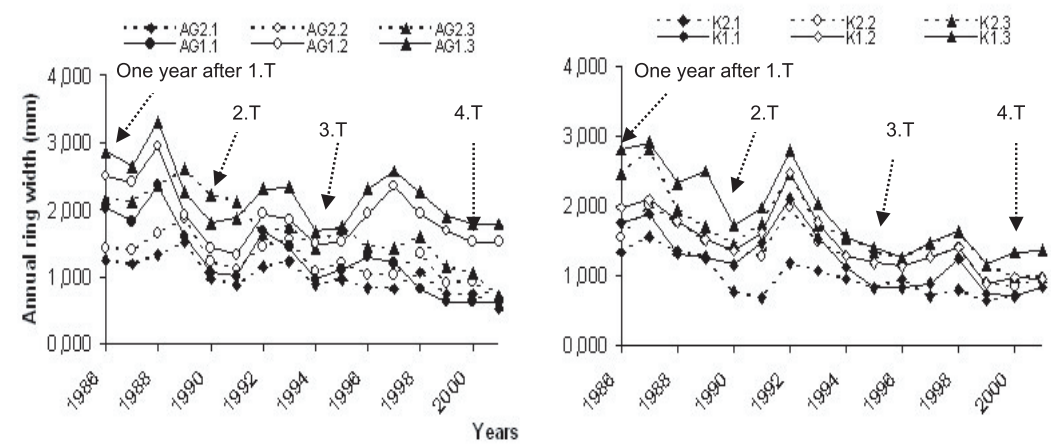

Figure 1. Variations in annual ring widths at breast height after thinning treatments.

Table I. The effect (\%) of thinning treatments on annual ring widths along the stem.

\begin{tabular}{|c|c|c|c|c|c|c|c|c|}
\hline \multirow[t]{2}{*}{ Height } & \multicolumn{2}{|c|}{ AG2 } & \multicolumn{2}{|c|}{ AG1 } & \multicolumn{2}{|c|}{ K2 } & \multicolumn{2}{|c|}{ K1 } \\
\hline & Moderate & Heavy & Moderate & Heavy & Moderate & Heavy & Moderate & Heavy \\
\hline 0.30 & 22.46 & 67.57 & 20.76 & 46.88 & 43.49 & 68.71 & 22.19 & 53.84 \\
\hline 1.30 & 23.58 & 71.24 & 49.53 & 90.60 & 43.18 & 72.50 & 22.13 & 54.52 \\
\hline 2.30 & 12.53 & 50.89 & 39.55 & 67.66 & 28.56 & 51.38 & 17.35 & 38.18 \\
\hline 4.30 & 9.69 & 33.99 & 32.58 & 51.72 & 23.04 & 34.07 & 20.54 & 28.48 \\
\hline 6.30 & 12.64 & 39.33 & 29.17 & 50.40 & 21.82 & 27.09 & 24.35 & 35.93 \\
\hline 8.30 & 7.94 & 31.76 & 23.81 & 43.51 & 10.54 & 18.86 & 18.64 & 29.13 \\
\hline 10.30 & & & 28.24 & 56.13 & & & 19.84 & 34.20 \\
\hline
\end{tabular}

the different site quality classes. The analysis showed that annual ring width between all paired treatments was significant; the results demonstrated that thinning treatments increased annual ring widths. The differences in mean annual ring widths at breast heights in thinned plots were apparent (Fig. 1). Generally heavy thinning treatment was found to be more affective on annual ring width than moderate treatment at the same site and site quality class (Tab. IX). The amount of carbohydrate produced by a tree depends mainly on the size of the crown or leaf surface and the ability of the roots to supply the foliage. After thinning, the amount of growing space for both the roots and crowns of residual trees is increased. When a tree is influenced by cutting a competing tree, any immediate acceleration of growth is largely from an increase in water and nutrient supplied by the roots $[30,49]$. This is the one of probable reasons for radial increases in individual trees after thinning.

The most proportional effect of thinning treatment on the annual ring width along the stem was found at a height of $1.30 \mathrm{~m}$, and in general, thinning treatments were more effective on the lower versus the upper part of stem (Tab. I). Because the annual accretion of xylem at upper or lower levels of stem is a function of the capacity of the foliage to synthesize carbohydrates and growth hormones, the size of the crown strongly determines the degree of stem taper. Stems of opengrown trees with long crowns tend to be more tapered than stems of trees with small crowns in closed stands. These differences are related to variations in both rate of xylem increment along the entire bole and in its vertical distribution along the stem. As height growth is independent of stand density and the rate of radial growth is greater along the bole of large-crowned trees than in those with small crowns, this alone causes increased taper in the former $[12,16,17,30]$. In addition, opengrown trees with large crowns tend to distribute significant amounts of metabolites to the lower stem, resulting in xylem incrementation there [30]. Tapered stems in thinned stands are also explained as a response to increased wind stress [32,59]. The larger crown thus causes higher wind stress and a further increased compensatory lower stem growth [39]. These are the most probable reasons for the increased annual ring increment in the lower versus the upper parts of stem through the effect of thinning.

In three of the four groups, the lowest mean values of latewood percentage were found for heavy thinning treatments. However, for some of these groups, the latewood percentages of the moderate thinning treatment were higher than other treatments. Therefore, no clear effect of thinning treatments on latewood percentage was observed (Tab. IX). The differences in annual ring widths due to thinning treatments were apparent. For this reason, analysis of the annual ring width and latewood percentage was chosen as an indirect indicator to explain the effects of thinning on latewood percentage. The analysis was performed between annual ring width and latewood percentage for each site and site quality class groups. According the results of correlation analysis for all groups, there appeared to be no significant correlation between annual ring width and latewood percentage $(P>0.05)$. The result showed that a significant increase occurred in annual ring widths after thinning, but this increase did not cause any clear change in 
Table II. ANOVA test for wood density. Sig. = Significance.

\begin{tabular}{lccccc}
\hline $\begin{array}{l}\text { Source of } \\
\text { variation }\end{array}$ & $\begin{array}{c}\text { Sum of } \\
\text { square }\end{array}$ & $\begin{array}{c}\text { Degrees of } \\
\text { freedom }\end{array}$ & Mean square & $F$ & $P$ (Sig.) \\
\hline Between groups & 0.012 & 11 & 0.001 & 1.151 & 0.361 \\
Within groups & 0.026 & 29 & & & \\
Total & 0.038 & 40 & & & \\
\hline
\end{tabular}

latewood percentage. Although there were conflicting results in the correlation between ring width and latewood percentage in the literature, the results obtained here agree with some earlier reports $[26,27,40]$ that radial increments increased but, late wood percentage was not affected significantly by thinning treatments in conifer species.

\subsection{Wood density}

Because of limited sample size for average tree density, the ANOVA analysis of tree density was grouped by treatment, site and site quality (i.e.; group 1: AG1.1 (1. site, medium site quality and control treatment); group 2: AG1.2 (1. site, medium site quality and moderate treatment),... group 12: K2.3 (2. site, poor site quality, heavy treatment)). A total of 12 groups and 41 trees were evaluated. According the results of the ANOVA test (Tab. II), there was no apparent evidence of any corresponding changes to both heavy and moderate thinning in mean wood density. In this study, the greatest effect of thinning treatment on annual ring width was found at breast height. In this respect, the relationships between annual ring widths and wood density were examined on samples obtained at a height of $1.30 \mathrm{~m}$. Pearson coefficient of correlation was found to be 0.051 and $P>0.05$. This demonstrates that at breast height of the stem, although thinning treatment affected annual ring width, wood density at the same height was not significantly affected by thinning treatments. This can be explained by the insignificant effect of thinning on latewood percentage which is closely related to wood density $[23,66]$.

There are conflicting results on the effect of thinning on wood density in the literature. Cown [14], Erickson and Harrison [18], Smith [50], Shepard and Shottafer [47], Barbour et al. [3], reported that wood density was reduced by thinning treatments. On the other hand, there are some reports that thinning treatments cause an increase on wood density $[35,62,63]$. Hapla reported that thinning has a minor effect on wood density [20]. Zobel and van Buijtenen listed a number of publications on the relationship between thinning treatments and wood density, and based on the general consensus concluded that wood density was not greatly effected by thinning [65]. Some other researchers supported the idea that thinning has little or no effect on wood density $[4,22,26,28,31,38-40,45,46,66]$.
Table III. ANOVA test for fibre length.

\begin{tabular}{|c|c|c|c|c|c|c|}
\hline & & Sum of square & $d f$ & Mean square & $F$ & $P$ \\
\hline \multirow[t]{3}{*}{ AG2 } & Between groups & 1.076 & 2 & 0.538 & 3.328 & 0.037 \\
\hline & Within groups & 43.663 & 270 & 0.162 & & \\
\hline & Total & 44.740 & 272 & & & \\
\hline \multirow[t]{3}{*}{ AG1 } & Between groups & 5.207 & 2 & 2.604 & 22.862 & 0.000 \\
\hline & Within groups & 28.700 & 252 & 0.114 & & \\
\hline & Total & 33.907 & 254 & & & \\
\hline \multirow[t]{3}{*}{ K2 } & Between groups & 2.464 & 2 & 1.232 & 9.518 & 0.000 \\
\hline & Within groups & 32.615 & 252 & 0.129 & & \\
\hline & Total & 35.079 & 254 & 0.129 & & \\
\hline \multirow[t]{3}{*}{ K1 } & Between groups & 2.532 & 2 & 1.266 & 13.723 & 0.000 \\
\hline & Within groups & 21.861 & 237 & 0.092 & & \\
\hline & Total & 24.393 & 239 & & & \\
\hline
\end{tabular}

\subsection{Fibre length}

Mean values for fibre length are given in Table IX. There was no clear evidence showing an effect of thinning treatments on fibre length. The ANOVA test showed that there were statistically significant $(P<0.05)$ differences among treatments (Tab. III). But, the results of multi comparison tests did not support any clear and parallel effect of treatments for all groups (Tab. IV). Thinning treatments increased fibre length at $\mathrm{K} 1$ and AG1. There was no statistically significant difference between control and moderate thinning based on the results of group AG2. Although, ANOVA test results showed a difference, multiple test results did not show any significant differences for group AG2. It can be thought that heavy thinning had a very minor effect on fibre length at AG2. There were no significant differences found between control and heavy thinning treatment in the group K2. But, the fibre length of moderate thinning was lower than the two other treatments in this group. Zobel, Harnnrup and Ekberg reported that tracheid length was not affected by thinning $[22,66]$. Koga et al. reported that thinning, in particular heavy thinning reduce tracheid lengths at breast height [26].

In this study, the sample trees were taken from plantations areas for which the seed sources were unknown. According to Panshin and de Zeeuw, "Silvicultural treatments of stands of uncontrolled seed origin may result in some improvement of wood qualities associated with the rate of growth however, silvicultural treatments can not yield any modification of the trees' cellular characteristics that can be transmitted to their progeny" [43]. Therefore to explain any effect of treatment, hereditability of wood characteristics must be well known. There is no specific study on the heritability of fibre length of Turkish red pine (Pinus brutia Ten.) in Turkey. Pinus radiata fibre length heritability was reported to be high by Haygreen and Bowyer [23], but there are some reports that the heritability of fibre length is low in some conifers $[43,51]$. Based on the results of this study and related literature, more information is 
Table IV. Tukey test for fibre length. Sig. = Significance.

\begin{tabular}{|c|c|c|c|c|c|c|c|}
\hline AG2 & $N$ & Subset & & AG1 & $N$ & & Subset \\
\hline Treatment & & 1 & 2 & Treatment & & & 1 \\
\hline Control & 95 & 1.731 & & Control & 80 & & 1.644 \\
\hline Heavy & 80 & & 1.998 & Moderate & 80 & & 1.644 \\
\hline Moderate & 80 & & 2.049 & Heavy & 113 & & 1.771 \\
\hline Sig. & & 1 & 0.578 & Sig. & & & 0.088 \\
\hline K2 & $N$ & Subset & & K1 & $N$ & & set \\
\hline Treatment & & 1 & 2 & Treatment & & 1 & 2 \\
\hline Control & 80 & 1.666 & & Moderate & 80 & 1.596 & \\
\hline Moderate & 80 & & 1.805 & Control & 95 & & 1.763 \\
\hline Heavy & 80 & & 1.917 & Heavy & 80 & & 1.838 \\
\hline Sig. & & 1 & 0.051 & Sig. & & 1 & 0.365 \\
\hline
\end{tabular}

Table V. ANOVA test results for compression strength.

\begin{tabular}{|c|c|c|c|c|c|c|}
\hline & & Sum of square & $d f$ & Mean square & $F$ & $P$ \\
\hline \multirow[t]{3}{*}{$\overline{\mathrm{AG} 2}$} & Between groups & 140.904 & 2 & 70.452 & 12.602 & 0.000 \\
\hline & Within groups & 654.102 & 117 & 5.591 & & \\
\hline & Total & 795.005 & 119 & & & \\
\hline \multirow[t]{3}{*}{ AG1 } & Between groups & 15.126 & 2 & 7.563 & 1.016 & 0.365 \\
\hline & Within groups & 870.875 & 117 & 7.443 & & \\
\hline & Total & 886.001 & 119 & & & \\
\hline \multirow[t]{3}{*}{$\mathrm{K} 2$} & Between groups & 10.935 & 2 & 5.468 & 1.400 & 0.251 \\
\hline & Within groups & 456.891 & 117 & 3.905 & & \\
\hline & Total & 467.826 & 119 & & & \\
\hline \multirow[t]{3}{*}{ K1 } & Between groups & 142.776 & 2 & 71.388 & 11.276 & 0.000 \\
\hline & Within groups & 740.712 & 117 & 6.331 & 0.000 & \\
\hline & Total & 883.487 & 119 & & & \\
\hline
\end{tabular}

Table VI. Tukey test for compression strength.

\begin{tabular}{lccccccc}
\hline AG2 & $N$ & \multicolumn{2}{c}{ Subset } & K1 & $N$ & \multicolumn{2}{c}{ Subset } \\
\hline Treatment & & 1 & 2 & Treatment & & 1 & 2 \\
Moderate & 40 & 39.531 & & Moderate & 40 & 39.179 & \\
Heavy & 40 & & 41.695 & Heavy & 40 & 39.415 & \\
Control & 40 & & 41.945 & Control & 40 & & 41.601 \\
Sig. & & 1.000 & 0.884 & Sig. & & 0.908 & 1 \\
\hline
\end{tabular}

needed for this specific species to determine if fibre length is affected by thinning.

\subsection{Strength properties}

The effect of thinning treatment on compression strength parallel to grain, modulus of rupture and modulus of elasticity were investigated.

The results of statistical analysis showed that there was no significant effect from the thinning treatments in two (AG1
Table VII. ANOVA test results for modulus of rupture.

\begin{tabular}{|c|c|c|c|c|c|c|}
\hline & & Sum of squar & $d f$ & Mean square & $F$ & $P$ \\
\hline \multirow[t]{3}{*}{$\overline{\mathrm{AG} 2}$} & Between groups & 33.757 & 2 & 16.879 & 1.438 & 0.243 \\
\hline & Within groups & 1021.213 & 87 & 11.738 & & \\
\hline & Total & 1054.970 & 89 & & & \\
\hline \multirow[t]{3}{*}{ AG1 } & Between groups & 2.377 & 2 & 1.188 & 0.064 & 0.938 \\
\hline & Within groups & 1624.900 & 87 & 18.677 & & \\
\hline & Total & 1627.277 & 89 & & & \\
\hline \multirow[t]{3}{*}{ K2 } & Between groups & 30.524 & 2 & 15.262 & 1.832 & 0.166 \\
\hline & Within groups & 724.863 & 87 & 8.332 & & \\
\hline & Total & 755.387 & 89 & & & \\
\hline \multirow[t]{3}{*}{ K1 } & Between groups & 710.849 & 2 & 355.425 & 24.344 & 0.000 \\
\hline & Within groups & 1270.231 & 87 & 14.600 & & \\
\hline & Total & 1981.080 & 89 & & & \\
\hline
\end{tabular}

Table VIII. ANOVA test results for modulus of elasticity.

\begin{tabular}{|c|c|c|c|c|c|c|}
\hline & & Sum of square & $d f$ & Mean square & $F$ & $P$ \\
\hline \multirow[t]{3}{*}{ AG2 } & Between groups & 1714005.09 & 2 & 857002.546 & 6.068 & 0.003 \\
\hline & Within groups & 12286809.80 & 87 & 141227.699 & & \\
\hline & Total & 14000814.90 & 89 & & & \\
\hline \multirow[t]{3}{*}{ AG1 } & Between groups & 3213181.09 & 2 & 1606590.546 & 2.341 & 0.102 \\
\hline & Within groups & 59701782.99 & 87 & 686227.391 & & \\
\hline & Total & 62914964.08 & 89 & & & \\
\hline \multirow[t]{3}{*}{$\mathrm{K} 2$} & Between groups & 375420.63 & 2 & 187710.313 & 0.540 & 0.585 \\
\hline & Within groups & 30241764.62 & 87 & 347606.490 & & \\
\hline & Total & 30617185.24 & 89 & & & \\
\hline \multirow[t]{3}{*}{ K1 } & Between groups & 630965.88 & 2 & 315482.939 & 0.908 & 0.407 \\
\hline & Within groups & 30236437.22 & 87 & 347545.255 & & \\
\hline & Total & 30867403.10 & 89 & & & \\
\hline
\end{tabular}

and K2) of the four groups. In the other groups, ANOVA test results (Tab. V) showed significant differences $(P<0.05)$, but Tukey test results (Tab. VI) did not show a clear effect from the treatments. It can be said for only one group (K2) that the thinning treatment decreased compression strength. There was no significant difference between control and heavy thinning treatment at $\mathrm{K} 1$. As a result, there appears to be no relationship between thinning and compression strength parallel to grain according to mean values (Tab. IX).

The effect of thinning treatments on bending properties, MOR and MOE were examined. Statistical results are given at Tables VII and VIII. The results obtained here showed that investigated strength properties were not affected by thinning treatments. Hapla reported that thinning treatments had little or no effect on wood strength properties [20,21]. As explained in section 3.2, many researchers reported that there was little or no relationship between thinning treatments and wood 
Table IX. Mean values of investigated wood properties.

\begin{tabular}{|c|c|c|c|c|c|c|c|c|c|c|c|c|c|c|c|c|c|c|}
\hline \multirow{3}{*}{$\begin{array}{l}\text { Group } \\
\text { (Site / site } \\
\text { quality) }\end{array}$} & \multirow{3}{*}{ Thinning } & \multirow{3}{*}{$\begin{array}{c}\text { Tree } \\
N \\
\end{array}$} & \multirow{2}{*}{\multicolumn{2}{|c|}{$\begin{array}{l}\text { Ring width } \\
\text { (mm) } \\
\text { (at } 1.30 \mathrm{~m})\end{array}$}} & \multirow{2}{*}{\multicolumn{2}{|c|}{$\begin{array}{l}\text { Latewood p. } \\
\qquad(\%) \\
(\text { at } 1.30 \mathrm{~m})\end{array}$}} & \multicolumn{4}{|c|}{$\begin{array}{c}\text { Wood density }\left(\mathrm{g} / \mathrm{cm}^{3}\right) \\
0 \% \mathrm{MC}\end{array}$} & \multirow{2}{*}{\multicolumn{2}{|c|}{$\begin{array}{l}\text { Fibre length } \\
\quad(\mathrm{mm})\end{array}$}} & \multirow{2}{*}{\multicolumn{2}{|c|}{$\begin{array}{c}\text { Compression } \\
\text { strength } \\
\left(\mathrm{N} / \mathrm{mm}^{2}\right)\end{array}$}} & \multirow{2}{*}{\multicolumn{2}{|c|}{$\begin{array}{c}\text { MOR } \\
\left(\mathrm{N} / \mathrm{mm}^{2}\right)\end{array}$}} & \multirow{2}{*}{\multicolumn{2}{|c|}{$\begin{array}{c}\mathrm{MOE} \\
\left(\mathrm{N} / \mathrm{mm}^{2}\right)\end{array}$}} \\
\hline & & & & & & & \multicolumn{2}{|c|}{$1.30 \mathrm{~m}$} & \multicolumn{2}{|c|}{ Whole tree } & & & & & & & & \\
\hline & & & $N$ & Mean & $N$ & Mean & $N$ & Mean & $N$ & Mean & $N$ & Mean & $N$ & Mean & $N$ & Mean & $N$ & Mean \\
\hline \multirow{3}{*}{$\begin{array}{c}\text { AG2 } \\
(1 / \text { poor })\end{array}$} & 1 & 5 & 80 & 1.00 & 80 & 23.70 & 20 & 0.541 & 120 & 0.530 & 95 & 1.644 & 40 & 41.945 & 30 & 62.837 & 30 & 4367.44 \\
\hline & 2 & 3 & 48 & 1.24 & 48 & 25.00 & 12 & 0.505 & 72 & 0.494 & 80 & 1.644 & 40 & 39.531 & 30 & 61.539 & 30 & 4222.29 \\
\hline & 3 & 3 & 48 & 1.72 & 48 & 20.58 & 12 & 0.538 & 72 & 0.522 & 80 & 1.771 & 40 & 41.695 & 30 & 62.838 & 30 & 4559.25 \\
\hline \multirow{3}{*}{$\begin{array}{c}\text { AG1 } \\
(1 / \text { medium })\end{array}$} & 1 & 3 & 48 & 1.27 & 48 & 33.89 & 12 & 0.519 & 84 & 0.512 & 80 & 1.731 & 40 & 40.648 & 30 & 61.759 & 30 & 4361.09 \\
\hline & 2 & 3 & 48 & 1.89 & 48 & 42.08 & 12 & 0.548 & 84 & 0.528 & 80 & 2.049 & 40 & 41.438 & 30 & 62.081 & 30 & 4745.93 \\
\hline & 3 & 3 & 48 & 2.41 & 48 & 25.39 & 12 & 0.529 & 84 & 0.521 & 113 & 1.998 & 40 & 41.357 & 30 & 62.122 & 30 & 4330.85 \\
\hline \multirow{3}{*}{$\begin{array}{c}\text { K2 } \\
\text { (2/poor) }\end{array}$} & 1 & 3 & 48 & 0.98 & 48 & 30.87 & 12 & 0.534 & 72 & 0.517 & 80 & 1.763 & 40 & 40.815 & 30 & 62.433 & 30 & 4244.97 \\
\hline & 2 & 3 & 48 & 1.37 & 48 & 30.70 & 12 & 0.536 & 72 & 0.518 & 80 & 1.596 & 40 & 41.440 & 30 & 62.179 & 30 & 4139.62 \\
\hline & 3 & 5 & 80 & 1.67 & 80 & 30.80 & 20 & 0.540 & 120 & 0.522 & 80 & 1.838 & 40 & 41.471 & 30 & 63.521 & 30 & 4294.51 \\
\hline \multirow{3}{*}{$\begin{array}{c}\mathrm{K} 1 \\
(2 / \text { medium })\end{array}$} & 1 & 3 & 48 & 1.23 & 48 & 35.95 & 12 & 0.521 & 84 & 0.477 & 95 & 1.666 & 40 & 39.179 & 30 & 56.416 & 30 & 3739.65 \\
\hline & 2 & 4 & 64 & 1.48 & 64 & 33.20 & 16 & 0.516 & 112 & 0.511 & 80 & 1.805 & 40 & 41.601 & 30 & 63.299 & 30 & 3927.92 \\
\hline & 3 & 3 & 48 & 1.89 & 48 & 26.25 & 12 & 0.489 & 84 & 0.487 & 80 & 1.917 & 40 & 39.415 & 30 & 59.759 & 30 & 3904.23 \\
\hline
\end{tabular}

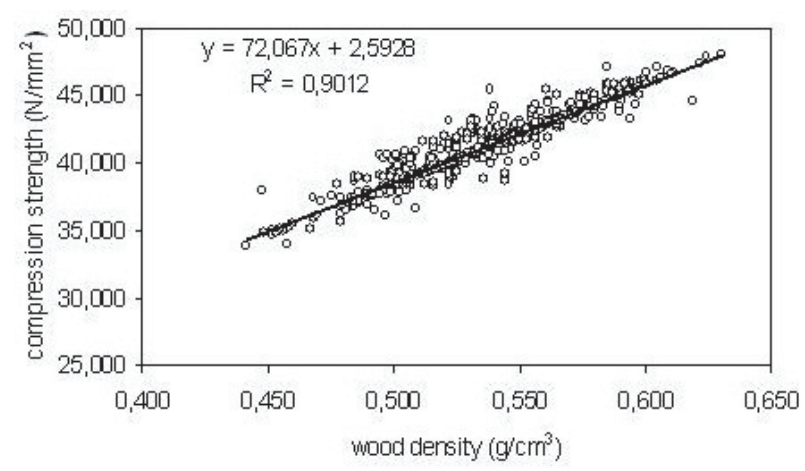

Figure 2. Relationship between compression strength and wood density.

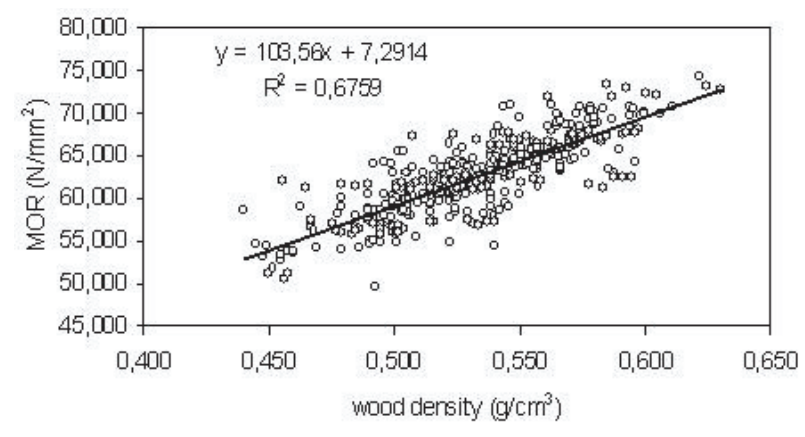

Figure 3. Relationship between MOR and wood density.

density. The results of this study support this observation. Significant positive linear relationships were found between wood density and strength properties except MOE (Figs. 2, 3, 4). Many researchers agreed that wood density is a good indicator of wood strength properties [9, 13, 23, 29, 43]. But, there were some previous report supporting weak relationship between MOE and density $[1,2,11,25,52,60,61]$.

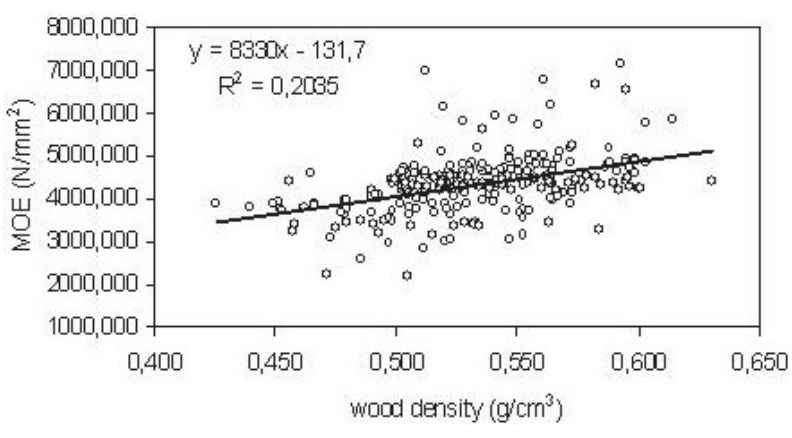

Figure 4. Relationship between MOE and wood density.

\section{CONCLUSION}

The conclusions can be summarized as follows:

- Radial growths at breast height increased with thinning treatments, especially after heavy thinning treatments.

- Latewood percentage at breast height was not affected significantly by thinning treatments.

- Mean wood density was not affected by thinning treatments.

- More information is needed about the investigated species to determine if fibre length is affected by thinning.

- Compression strength parallel to grain, MOR and MOE were not affected by thinning treatments.

- Positive linear relationships were found between wood density and MOR and wood density and compression strength.

As a result, thinning effects were found to have negligible influence on investigated wood properties. But, the thinning intensity range provides only a limited variation of the average ring width between treatments. Therefore the wood density variations were expected to be low. In addition, the seed source of samples taken from two plantations areas was 
unknown. Unfortunately, there is no specific study on the heritability of important wood properties of Turkish red pine ( $\mathrm{Pi}$ nus brutia Ten.). However, some literature is available on other pine species and they were helpful to explain some results. This research is the first study which investigated the effects of thinning on wood properties in Turkey. To make generalizations, more research is required on this subject. The current results suggest that thinning can produce improvements in annual ring width without any negative changes in latewood percentage and the investigated wood properties, although subsequent studies must be better designed to minimize genetic effects and maximize treatment effects.

Acknowledgements: This research is part of Ph.D. thesis supported by Istanbul University (Project number T/1176). I am grateful to Prof. Dr. Yener Goker, Prof. Dr. Nusret As, Prof. Dr. Unal Eler, Prof. Dr. Musa Genc, and Associate Prof. Dr. Erol Oktem for their valuable discussions and encouragement. I wish to thank the staff of Suleyman Demirel University, West Anatolian Forestry Research Institute, Forestry Administration of Isparta and Turkish Standards Institution. Thanks to Sue Quick Uner for revising the English.

\section{REFERENCES}

[1] Addis Tsehaye, Buchanan A.H., Walker J.C.F., A comparison of density and stiffness for predicting wood quality or density: The lazy man's guide to wood quality, J. Inst. Wood Sci. 13 (1995) 539-543.

[2] Addis Tsehaye, Buchanan A.H., Walker J.C.F., Selecting trees for structural timber, Holz Roh Werkst. 58 (2000) 162-167.

[3] Barbour R.J., Fayle D.C.F., Chauret G., Cook J., Karsh M.B., Ran S.K., Breast-height relative density and radial growth in mature Jack pine (Pinus banksiana Lamb.) for 38 years after thinning, Can. J. For. Res. 24 (1994) 2439-2447.

[4] Barrett J.D., Kellogg R.M., Lumber quality from second growth managed forests, juvenile wood what does it mean to forest management and forest products? Proceedings of a cooperative technical workshop, Forest Products Research Society/Society of American Foresters, by the Forest Products Research Society, 1984, ISBN: 0-935018-29-8.

[5] Bektas I., Alma M.H., As N., Gundogan R., Relationship between site index and several mechanical properties of Turkish calabrian pine (Pinus brutia Ten.), For. Prod. J. 53 (2003) 27-31.

[6] Bendtsen B.A., Properties of wood from improved and intensively managed trees, For. Prod. J. 28 (1978) 69-72.

[7] Berlyn G.P., Miksche J.P., Botanical microtechnique and cytochemistry. Iowa State University Press, Ames, Iowa, USA, 1976.

[8] Bozkurt Y., Erdin N., Agaç Teknolojisi (Tree technology), Ý.Ü. Yayin No (Pub. No.): 3998, Istanbul, 1997 (in Turkish), ISBN: 975404-449-X

[9] Brazier J.D., Howell R.S., The use of a breast height core for estimating selected whole tree properties of Sitka spruce, Forestry 52 (1979) 177-185.

[10] Brix H., Mitchell A.K., Effects of thinning and nitrogen fertilization on xylem development in Douglas-fir Can. J. For. Res. (1983) $121-128$

[11] Cave I.D., Walker J.C.F., Stiffness of wood in fast-grown plantation softwoods: the influence of microfibril angle, For. Prod. J. 44(5) (1994) 43-48.

[12] Ceylan B., Mugla yoresindeki genc kizilcam mescerelerinde ilk aralama mudahaleleri uzerine silvikulturel arastırmalar (The silvicultural research of the first thinning interventions on the young Pinus brutia Ten stands in Mugla region), OAE Teknik Bulten No: 196, Ankara, Turkey, 1988, (in Turkish with English summary).

[13] Cown D.J.,Young G.D., Burdon R.D., Variations in wood characteristics of 20-year-old half-sib families of Pinus radiata, N. Z. J. For. Sci. 22, (1992) 63-76.

[14] Cown D.J., Effects of severe thinning and pruning treatments on the intrinsic wood properties of radiata pine, N. Z. J. For. Sci. 3, (1973) 379-389.

[15] Dinwoodie J.M.,The relationship between fiber morphology and paper properties: A rewiev of literature, TAPPI J. 48 (1965) 440-447.

[16] Eler U., Antalya bolgesi dogal kizilcam mescerelerinde aralama ve hazirlama kesimlerinin artim ve buyume yonunden etkileri, OAE Teknik Rapor No: 21, Ankara, 1984 (in Turkish).

[17] Eler U., Effect of thinning and preparatory cutting on increment and growth for natural Pinus brutia stands in Antalya forest region, OAE. Technical Bulletin: 203, Ankara, Turkey, 1988 (in Turkish with English summary).

[18] Erickson H.D., Harrison A.T., Douglas-fir wood quality studies, Part: I Effects of age and stimulated growth on wood density and anatomy, Wood Sci. Tech. 8 (1974) 207-226.

[19] Guller B., The effects of different silvicultural treatments on technological properties of Pinus brutia Ten wood, Doctoral Thesis, Istanbul University of Forestry Faculty, 2004 (in Turkish with English summary)

[20] Hapla F., How to bring into accord the silvicultural management and the end-users' interests in case of the Douglas fir., Timber management toward wood quality and end product value, Proceedings of the CTIA/IUFRO International Wood Quality Workshop, August 18-22, 1997 Quebec City, Canada.

[21] Hapla F., Villanueva J.V., Gonzalez-Molina J.M., Effect of silvicultural management on wood quality and timber utilisation of Cedrus atlantica in the European Mediterranean area, Holz Roh Werkst. 58 (2000) 1-8.

[22] Harnnrup B., Ekberg I., Age-age correlations for tracheid length and wood density in Pinus sylvestris, Can. J. For. Res. 28 (1998) $1373-1379$.

[23] Haygreen J.G., Bowyer J.L., Forest products and wood science, 3rd edition, Iowa State University Press, USA, 1996.

[24] Jozsa L.A., Brix H., The Effects of Fertilization and Thinning on Wood Quality of a 24 Year Old Douglas Fir. Stand, Can. J. For. Res. 19 (1989) 1137-1145.

[25] Kijidani Y., Kitahara R., Effects of basic wood properties on strength and stiffness in bending of Cryptomeria japonica timbers, J. Soc. Mat. Sci. Japan 54 (2005) 377-380.

[26] Koga S., Tsutsumi J., Oda K., Fujimoto T., Effects of thinning on basic density and tracheid length of Karamatsu (Larix leptolepis Gord.), Makuzai Gakkaishi, 42 (1996) 605-611.

[27] Koga S., Tsutsumi J., Oda K., Fujimoto T., Effects of thinning on the wood structure in annual growth rings of Japanese larch (Larix leptolepis), IAWA J. 18 (1997) 281-290.

[28] Koga S., Zhang S.Y., Relationships between wood density and annual growth rate components in Balsam fir (Abies balsamea), Wood Fiber Sci. 34 (2002) 146-157.

[29] Kollmann F.F.P., Côte W.A., Principles of wood science and technology, I Solid wood, Springer-Verlag, Berlin - Heidelberg, Germany, 1968.

[30] Kozlowski T.T., Growth and development of trees, Vol. II, 1971, Academic Press, New York and London, pp. 110-111.

[31] Kucera B., A hypothesis relating current annual height increment to juvenile wood formation in Norway spruce, Wood Fiber Sci. 26 (1994) 152-167.

[32] Larson P.R., Stem forms of young Larix as influenced by wind and pruning, For. Sci. 11 (1965) 412-424. 
[33] Larson P.R., Wood formation and the concept of wood quality, School of Forestry, Yale University, Bull. No. 74, 1969.

[34] Macdonald E., Hubert J., A review of the effects of silviculture on timber quality of Sitka spruce, Forestry 75 (2002) 107-138.

[35] Macpeak M.D., Burkart L.F., Weldon D., Comparison of grade, yield, and mechanical properties of lumber produced from young fast-grown and older slow-grown planted Slash pine, For. Prod. J. 40 (1990) 11-14.

[36] Markstrom D.C., Troxell H.E., Boldt C.E., Wood properties of immature ponderosa pine after thinning, For. Prod. J. 33 (1983) 33-36.

[37] McKimmey M.D., The genetic potential for improving wood, Proceedings of Symposium on Douglas-fir: Stand Management for the Future, University of Washington, Seattle, WA, June 18-20, 1985.

[38] McKimmey M.D., The effect of forest management practices on wood properties, juvenile wood what does it mean to forest management and forest products? Proceedings of a Cooperative Technical Workshop, Forest Products Research Society/Society of American Foresters, Published by the For. Prod. Res. Society, USA, 1986.

[39] Morling T., Effects of nitrogen fertilization and thinning on growth and clear wood properties in Scots pine (P. sylvestris), Doctoral Thesis, Swedish University of Agricultural Sciences, Umea, Sweden, 1999.

[40] Moschler W.W., Dougal E.F., McRae D.D., Density and growth ring characteristics of Pinus taeda L. fallowing thinning, Wood Fiber Sci. 21 (1989) 313-319.

[41] Nyland R.D., Silviculture concepts and applications, 2nd edition, McGraw-Hill Series in Forest Resources, 2002.

[42] Odabasi T., Korudağı kızılçam plantasyonlarında mecere bakımı uzerine arastırmalar (Investigation on tending of $P$. brutia plantations in Korudagi), J. For. Faculty Istanbul A (1981), 75-104.

[43] Panshin A.J., De Zeeuw C., Textbook of wood technology, McGraw-H1ll Series in Forest Resources, USA, 1980.

[44] Pape R., Influence of thinning and tree diameter class on the development of basic density and annual ring width in Picea abies, Scand. J. For. Res. 14 (1999) 27-37

[45] Parker M.L., Hunt K., Warren W.G., Kennedy R.W., Effect of thinning and fertilization on intra-ring characteristics and kraft pulp yield of Douglas-fir, Applied Polymer Symposium No. 28, 1976, pp. 1075-1086.

[46] Pearson R.G., Ross B.E., Growth rate and bending properties of selected Loblolly pines, Wood Fiber Sci. 16 (1984) 37-47.

[47] Shepard R.K., Shottafer J.E., Effect of early release on specific gravity and wood yield of black spruce, For. Prod. J. 40 (1990) 18-20,

[48] Smith D., Wood quality of loblolly pine after thinning, U.S. For. Serv. Res. Paper 89, 1968.

[49] Smith D.M., Larson B.C., Keltym J., Ashton P.M.S., The practice of silviculture: applied forest ecology, Chapter 3: The response of individual trees to thinning and pruning, Wiley and Sons Inc., New York, 1996
[50] Smith J.H.G., Influences of spacing on radial growth percentage latewood of Douglas -fir, western hemlock, and western red cedar, Can. J. For. Res. 10 (1980) 169-175.

[51] Stranger, T.K., Variation and genetic control of wood properties in the juvenile core of Pinus patula grown in South Africa, Doctoral Diss., North Caroline State University, Department of Forestry, 2003.

[52] Treacy M., Evertsen J., Dhubhain A.N., A comparison of mechanical and physical wood properties, COFORD, Finland, 2000.

[53] TS 642 (same ISO 554), Standard atmospheres for conditioning and/or testing; specifications, Turkish Standard Institute, 1997.

[54] TS 2474 (same ISO 3133), Wood- Determination of ultimate strength in static bending, Turkish Standard Institute, 1977.

[55] TS 2478 (same ISO 3349), Wood-Determination of modulus of elasticity in static bending, Turkish Standard Institute, 1978.

[56] TS 2595 (same ISO 3787), Wood-Determination of ultimate stress in compression parallel to grain, Turkish Standard Institute, 1977.

[57] Usta H.Z., A study on the yield of Pinus brutia Ten. plantations, Turkish Forestry Research Institute Technical Bull. 219, 1991 (in Turkish with English summary).

[58] Usta H.Z., Akdeniz bolgesindeki kızılçam kultur ormanlarında ilk aralamaların artım ve buyumeye etkisi (Non-commercial thinning effects on radial and height increment of Pinus brutia Ten. plantations in Mediterranean region of Turkey), Batı Akdeniz Ormanc1lık Arastırma Mudurlugu, Teknik Bulten No. 5, Antalya, 1996 (in Turkish with English summary).

[59] Valinger E., Effects of wind sway on stem form and crown development of Scots pine (Pinus sylvestris L.), Aust. For. 55 (1992) $15-21$.

[60] Walker J.C.F., Butterfield B.G., The importance of the microfibril angle for the processing industries, N. Z. For. 40 (1996) 34-40.

[61] Wang S.Y., Wang H.L., Effects of moisture content and specific gravity on static bending properties and hardness of six wood species, J. Wood Sci. 45 (1999) 127-133.

[62] Wang X., Ross R., Erickson J.R., Forsman J.W., McClellan M., Barbour R.J., Pellerin R.F., Nondestructive evaluation of standing trees with stress wave methods, 12th International Symposium on Nondestructive Testing of Wood, University of Western Hungary, Sopron, Proceedings, 2000, pp. 197-206,

[63] Wodzicki T.J., Natural factors affecting wood structure, Wood Sci. Technol. 3 (2001) 5-26.

[64] Zhang S.Y., Effect of growth rate on wood specific gravity and selected mechanical properties in individual species from distinct wood categories. Woo Sci. Tech. 29 (1995) 451-465.

[65] Zobel B.J., Van Buijtenen J.P., Wood variation: Its causes and control, Springer-Verlag, Berlin, 1989.

[66] Zobel B.J., Silvicultural effects on wood properties, Instituto de Pesquisas Florestais 2 (1992) 31-38. 